\title{
Narratives underlying research in African river basin management
}

\author{
Fritz Kleinschroth ${ }^{1}$ (1) Caroline Lumosi ${ }^{2} \cdot$ Amare Bantider $^{3} \cdot$ Yilikal Anteneh $^{3} \cdot$ Caroline van Bers $^{2}$
}

Received: 5 March 2021 / Accepted: 12 September 2021 / Published online: 5 October 2021

(c) The Author(s) 2021

\begin{abstract}
River modifications through hydropower dams and other infrastructure have far-reaching economic, ecological and social effects that are viewed in highly contrasting ways depending on underlying narratives. As part of a Euro-African research consortium funded by the European Commission we studied pathways for sustainable river basin management in the OmoTurkana basins in Ethiopia and Kenya. Based on a literature review, stakeholder workshops, targeted interviews and considering our own positionality, we identified underlying narratives related to (a) economic transformation and modernization, (b) indigenous rights and (c) nature conservation, which were all connected through water, energy, food and ecosystems within a (d) landscape nexus. Yet, we also identified a (e) living museum narrative suggesting that international advocacy for indigenous rights and nature conservation is a means through which Western societies want to preserve African societies in an "undeveloped" state. National governments use this narrative to silence external critique, while the tourism industry promotes it to advertise visits to pastoralist tribes. This narrative reveals powerful, yet largely ignored hindrances for collaborative projects resulting from cultural and historical biases in Euro-African collaborations. Based on our analysis, we argue that international research projects in sustainability sciences need to increase the transparency of open and hidden narratives that influence research directions and power relationships between scientific partners, also those using mostly technically-driven approaches. We emphasize that African landscapes are not to be viewed as living museums, and collaborative research should be based on fairness, respect, care, and honesty to allow for multiple narratives that underlie research.
\end{abstract}

Keywords Watersheds $\cdot$ Positionality $\cdot$ Scientific collaboration $\cdot$ Landscape approach $\cdot$ Sustainable development $\cdot$ Waterenergy-food nexus

Handled by Mekuria Argaw, Addis Ababa University,College of Natural Sciences Center for Environmental Science, Ethiopia.

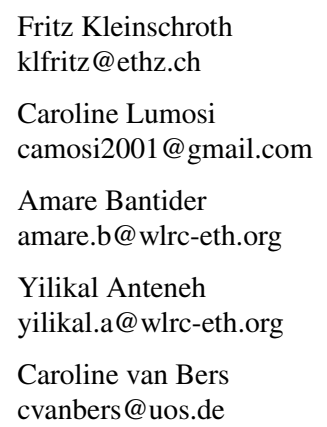

1 Ecosystem Management, Department of Environmental Systems Science, ETH Zürich, Universitätsstr. 16, 8092 Zürich, Switzerland

2 Institute of Environmental Systems Research, Osnabrück University, Barbarastr. 12, 49076 Osnabrück, Germany

3 Water \& Land Resource Centre, Addis Ababa University, Diaspora Square Megenagna, Rahem Building, Addis Ababa, Ethiopia

\section{Introduction}

Infrastructure development is at the top of the African development agenda and therefore a "hot topic" for research projects (Enns 2018). As part of this, river management projects such as large hydropower dams and new irrigation schemes and the question of who wins and who loses from them attract a great deal of public and scientific attention, especially in transboundary settings (Rieu-Clarke 2015; Di Baldassarre et al. 2019). It is increasingly accepted that narratives, defined as widely understood streams of argumentation and meaning-making, play a strong role in the framing of research on development and sustainability transitions (Roe 1991; Luederitz et al. 2017). Yet, it remains poorly understood how international scientific projects are influenced by narratives and how this shapes collaborative scientific approaches. As a result of the trade-offs between infrastructure development, nature conservation and social equity, sustainability narratives can be strongly diverging 
between actors and between scales, thus providing slippery ground for scientific research (Molle 2008; Evans et al. 2014). Here, we aim to reveal the most dominant narratives that influence Euro-African research collaborations, using as one example our work on the sectoral nexus of water, energy and food (WEF Nexus) in the Omo-Turkana basins in Ethiopia and Kenya, funded by the European Commission (EC).

In 2007 the EC and the African Union entered into a strategic partnership for science and technology cooperation (European Commission 2018). Since then, 310 grants involving African Union partners were approved, a trend that is set to continue with the launch of an Africa-Europe Innovation Partnership in 2019 (European Commission 2019). Often researchers-like the authors of this paperwhose research is funded by European or other non-African sources to address resource distribution issues in African countries, are faced with inherent ethical and epistemological dilemmas. Given a history of postcolonial and exploitative structures in research undertaken by "foreigners for Africa" (Mawere and van Stam 2019), a reflection on underlying agendas and narratives that underpin such forms of collaboration is particularly important (Mlambo 2006). This means, the selection of a particular research direction requires transparency and a critical reflection about (a) the choice of specific research questions and (b) how personal and professional backgrounds, experience and preferences shape the research approach. Here, we reflect on our experience with narratives that we encountered during four years of work in a collaborative research project. The DAFNE project stands for Decision Analytic Framework to explore the water-energy-food Nexus in complex transboundary water resource systems of fast developing countries. The project partners worked with stakeholders to identify multiple, sometimes competing interests in transboundary river basins. The project consortium included ten European and four African research organizations, selected to represent complementary disciplines needed to jointly develop a framework to explore alternative pathways for advancing sustainable transboundary water management in the OmoTurkana basins (DAFNE consortium 2016).

Narratives form part of postmodern discursive theory (Lyotard 1984; Brodkey 1987) in that they provide a stream of argumentation or "meaning-making" (Snow et al. 1986; Williams 2014), giving meaning to social processes that can be analytically described. The role of narratives is increasingly being recognized in the study of policy processes (Shanahan et al. 2011) including the transformative role they can have in environmental decision-making (Lakoff 2010; Veland et al. 2018). Narratives often contain archetypes that are intentionally generalized to highlight the common characteristics, and the contrasting features between them (Luederitz et al. 2017). As such, narratives have been described as self-validating, as they tend to produce evidence rather than being based on evidence (Molle 2008). Consequently, narrative pluralism is crucial to allow for epistemic uncertainty that cannot simply be treated as a technical problem (Cabello et al. 2018), which is often the case in international and intercultural research projects. In the water sector, narratives are typically linked to specific water uses that are mutually exclusive, for example, the use of lakes for drinking water versus the use of river water for irrigation before it flows into that lake (Grasham 2016).

With our analysis we go one step further by also considering narratives that are based on the imputation (sensu Nickerson 1999) of what others want. That means one group of actors who operate at a certain scale within their sphere of interest assume and reproduce a narrative that is supposedly used by another, largely disconnected group of actors. Such framings of contrasting and disconnected narratives occur when global sustainability agendas and local realities are not aligned. In combination with opaque powerrelationships between various groups of actors involved in the discourse, such misalignment can lead to those involved talking at cross-purposes, and eventually to conflicts (Reed and Bruyneel 2010; Wilson 2012). Within a discourse that takes place in a disconnected way across scales, we therefore also consider narratives that are based on imputations of what others want as being highly relevant.

In this study, we develop a typology of narratives that reflect what we observed during our research on water resource-based infrastructure development in the Omo-Turkana basins. We argue that a critical reflection on narratives among different actor groups at multiple scales, including within our own research projects, may help to identify linkages and common ground between various actors and ultimately develop a common understanding of a resource management issue. The outcome of this process may provide pathways to improved and more sustainable management decisions and contribute to the design of future Euro-African collaborative projects.

\section{The case of the Omo-Turkana basins}

The Omo River originates in the Ethiopian highlands, and then meanders through the country's hot lowlands and ultimately provides the main water source for Lake Turkana, the world's largest permanent desert lake which is in both Ethiopia and Kenya (Ojwang et al. 2017). Large infrastructural developments in the middle and upper parts of the Omo River have been underway for the last two decades (Velpuri and Senay 2012). Most notably, Gibe III, one of the largest hydropower dams in Africa, started operations in 2016 (Fig. 1). Another dam of a similar size, Koysha, is currently under construction (Wolka et al. 2018). Further downstream, the Kuraz sugar development project will bring an estimated 


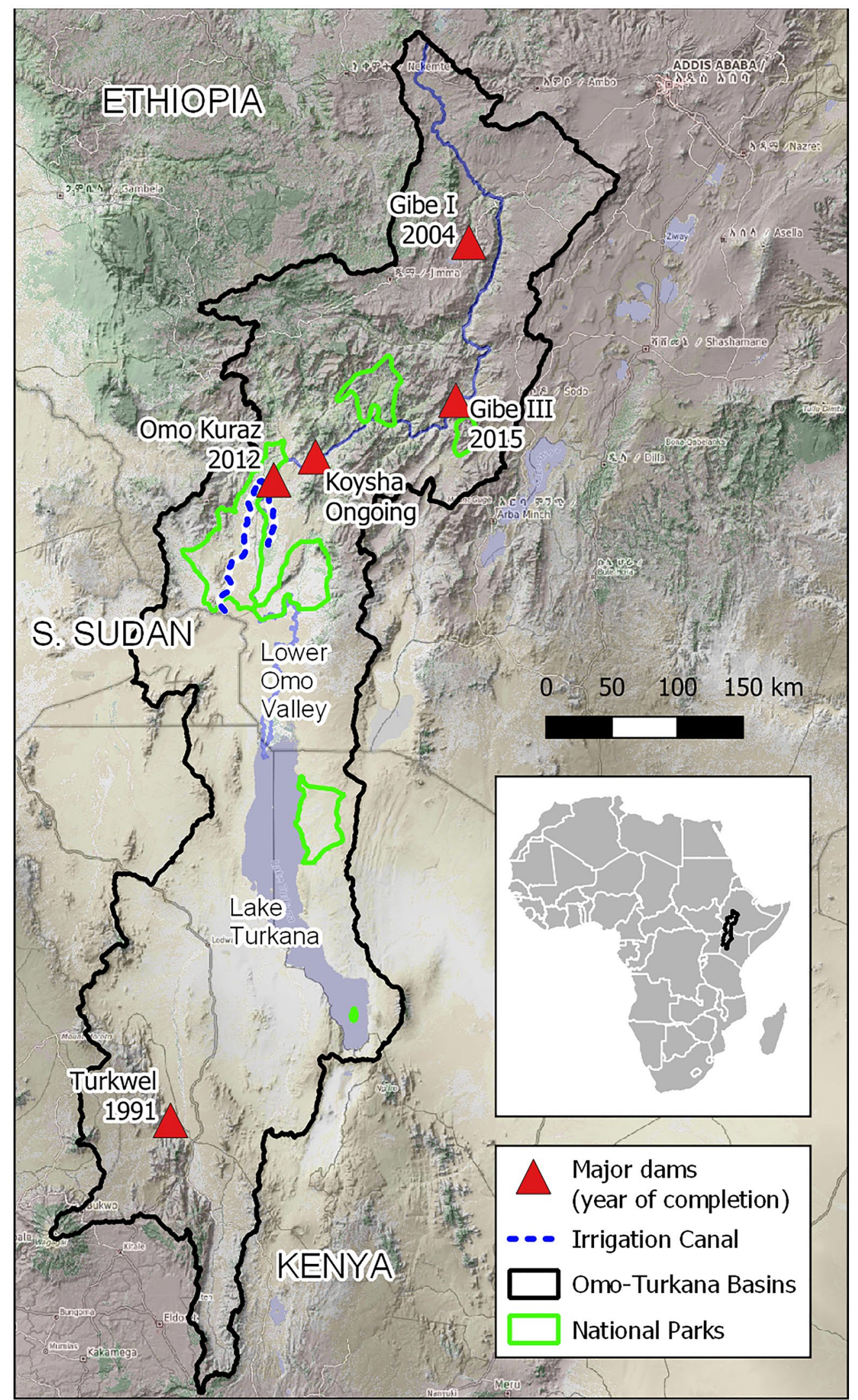

Fig. 1 Overview of the Omo-Turkana basins (Sources: OpenStreetMap, World Database of Protected Areas, own observations) 
Fig. 2 Construction of an irrigation canal near Omo National Park in southeast Ethiopia (photo by F. Kleinschroth, 29/03/2019)

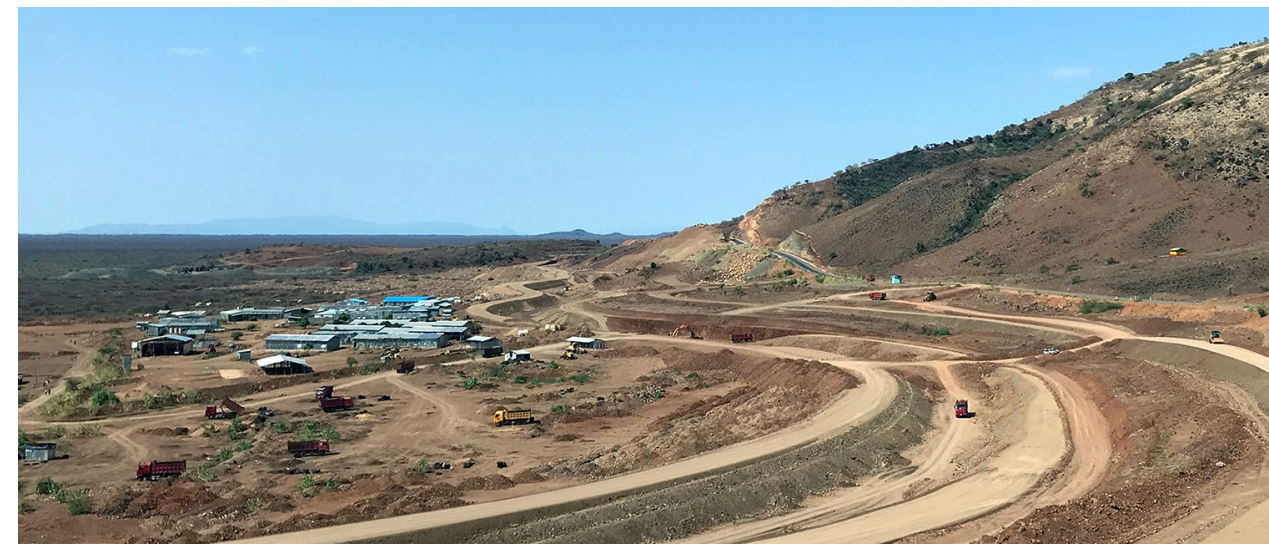

area of 80,000 ha of former wood- and grassland including some land within Omo and Mago National Parks into sugar cane production (Kamski 2019). The Kuraz sugar plantation project is currently excavating irrigation canals that are, thus far, $190 \mathrm{~km}$ in length (Fig. 2, own observations based on satellite imagery).

The case of Omo-Turkana river basin management is discussed at local, regional and international levels due to the significant implications of infrastructure projects for the livelihoods of rural agro-pastoralist communities, often referred to as indigenous peoples (Hodbod et al. 2019). Dam construction and water abstractions are changing the discharge and seasonal flow dynamics and thus affect downstream communities who depend on seasonal flooding for recession agriculture, where floods provide soil nutrients and moisture (Ayalew 2009), and on fisheries that are expected to decline with reduced hydrological dynamics in Lake Turkana and the Omo Delta (Kolding et al. 2016; Gownaris et al. 2017). These two distinct uses of water resources among different actor groups could potentially lead to conflicting or competing interests particularly against the backdrop of a changing climate (Carr 2017). In the wider Omo delta area alone, a population of up to 40,000 inhabitants is potentially affected by changes in the water regime (Amos et al. 2021).

\section{Approach and methods}

To identify dominant narratives, we followed a three-step grounded theory approach of coding qualitative information (Corbin and Strauss 1990; Charmaz 2006; Chun Tie et al. 2019). In a first step, we identified an initial set of three narratives about the internal and external perceptions of the South Omo region in Ethiopia, based on the authoritative work of David Turton, an anthropologist working in the region since 1968 (Gil-Romera et al. 2011). Turton (2011) suggests that different groups see the region as either "wilderness" (a natural area in need of protection), "wasteland" (an unused area in need of development) or "home" (a place of living and identification), depending on their interests. Girke (2013) largely confirmed these three categories, calling them "boundary", "resource" and "homeland". The initial knowledge of these categories influenced our second step, which was the inductive collection of information from (a) interviews with scientists, resource managers and community representatives working in the Omo-Turkana region, (b) participant observations during two field trips to the Lower Omo Valley, including visits to pastoralist settlements and interviews with local administrators and park managers, and (c) informal observations during three rounds of workshop sessions with stakeholders including government and non-governmental representatives, held in Addis Ababa and Nairobi (Supplementary Table S1). These workshops were run by the DAFNE project to understand tradeoffs between different interests and design integration tools based on a watershed-based nexus approach to sustainable development, which we consider a narrative in itself.

As organizers of both the stakeholder workshops and the fieldtrips to the basin, we were increasingly conflicted in navigating our roles as researchers as well as integrating the different views and perceptions amongst ourselves as researchers, amongst the stakeholders in different positions of power and between the researchers and the stakeholders. It is from these observations and experiences that we started reflecting on our own roles as European-African researchers in an African context and saw the need to add an additional, more diffuse, narrative to the analysis. This narrative was based on emerging patterns such as the links between tourism and westernization, development and conservation or preservation, and European and African epistemologies. During several virtual and two physical meetings in Germany, the author team shared and discussed insights from field visits and stakeholder workshops. From these meetings, keywords and phrases emerged such as modernization, living museums, development transformation, backwardness, community marginalization, preservation, and indigeneity. These issues 
did not seem well covered by the initial four narratives identified.

In a third step, we then reviewed scientific literature, grey literature and other online sources such as blogs and discussion forums to undertake a more focused coding of the patterns emerging from the field and to contextualize them within the literature. A search for "(Omo OR Turkana) AND (Gibe OR dam OR irrigation)" generated 54 hits on Web of Science (as of 18/08/2020). After making a selection based on title and abstract, 22 references remained that explicitly refer to river management in the Omo and/ or Turkana basins. By contrast, water management in the Omo-Turkana basins has been widely discussed in political and non-scientific contexts especially on an international level (e.g. Human Rights Watch 2012; UNEP 2013; The Oakland Institute 2019), and these contexts strongly shaped the narratives underlying this case. It was not possible to quantify the available non peer-reviewed online sources, as this would require an exhaustive review of thousands of articles (Google: 5,390,000 hits, Google Scholar: 32,800). Key quotes from each source were collected and decoded according to at least five narratives identified during the three steps of the research (Supplementary Tables S2, S3), leaving the possibility for additional narratives that would emerge during the process. We then established each narrative in written form through several rounds of co-editing and coding of information.

\section{Authors' positionality}

Our own positionality played a key role in the process of drafting the narratives. Based in Germany, Ethiopia and Switzerland we were all engaged as researchers in the DAFNE project. Our common entry point was an evidence-based science perspective with the goal of bringing representatives of different sectors together to address resource management in an African river basin, especially the contested aspects. Our respective scientific disciplines range from land-use planning, ecology, natural resource management and engineering, to social sciences and human geography. In addition, we identify with different cultures. As European researchers based in Europe and carrying out research on Africa, the first and fifth authors were aware that they were entering the process from an external and privileged position. Their views emanated from a conservation imperative, where protection and restoration of ecosystems is promoted as a basis for sustainable development and tends to argue against large-scale infrastructure development. In contrast, the third and fourth authors are Ethiopians living in Ethiopia who are, while not based in the study area, familiar with the regional context. They entered the research process with a view to supporting country-wide inclusive and transformative development by means of investment in large infrastructure which would benefit citizens of the nation including the local residents and without compromising biodiversity conservation. The second author is a Kenyan citizen based in Europe, thus having close interactions with both European project partners and having a good understanding of the unique challenges of the interlinked water, energy, food security issues on the ground. In addition, she is familiar with the East-African cultural nuisances and the unspoken rules of conducting research in Africa. In this position, she was also expected to play the role of a cultural mediator between European and African partners, though this expectation only emerged as the project developed.

While we hold different positions regarding the study area, we argue that the identification of narratives is one way to make contrasting values visible which is a basis for collaborative research. We made power differences explicit by drawing on our different experiences in the DAFNE project. Our unique scientific, disciplinary and cultural differences prompted us to reflect on how narratives and implicit biases influence the role of European and African collaboration when conducting research in Africa.

\section{Results}

We identified five narratives consisting of multiple elements that are visible at different scales and influence the perspectives and actions of different actors (Table 1). The first three narratives are largely in line with the three categories identified by Turton (2011): The economic transformation and modernization narrative is strongest on national scales and gives the highest priority to infrastructure development and export-oriented agriculture. The indigenous rights narrative is most visible at the international scale and focuses on the rights of minorities who live in the region and are affected by infrastructure construction and resource exploitation. The nature conservation narrative argues that functioning ecosystems are the foundation of human well-being and is generally less visible. Our work in the DAFNE project with its focus on the water-energy-food nexus provided the framing for the landscape nexus narrative, which attempts to resolve conflicting demands through the optimal allocation of natural resources based on empirical evidence in decision-making processes and thus avoid "lose-lose" situations. Finally, as an outcome of the more in-depth analysis throughout the project, the living museum narrative is based on the assertion by national governments that foreign organizations and researchers idealize pristine landscapes and aim to keep them in a historic state, where indigenous lifestyles are romanticized, preserved and photographed. 
Table 1 Overview of five narratives and their main characteristics in relation to the installation of hydropower dams and irrigation agriculture in the Omo-Turkana basin (see Supplementary Information for background)

\begin{tabular}{|c|c|c|c|c|}
\hline Narrative & Who uses it? & Visible on what scale? & Linkage with other narratives & $\begin{array}{l}\text { Who benefits (financially or } \\
\text { morally)? }\end{array}$ \\
\hline Economic transformation & $\begin{array}{l}\text { Large parts of governments, } \\
\text { investors, urban public }\end{array}$ & Local to national & $\begin{array}{l}\text { Often based on nexus narra- } \\
\text { tive, can be conflicting with } \\
\text { conservation and indig- } \\
\text { enous rights }\end{array}$ & $\begin{array}{l}\text { Investors, companies, elec- } \\
\text { tricity users, politicians }\end{array}$ \\
\hline Indigenous rights & $\begin{array}{l}\text { International NGO's, } \\
\text { Researchers }\end{array}$ & Global & $\begin{array}{l}\text { In opposition to economic } \\
\text { transformation narrative }\end{array}$ & $\begin{array}{l}\text { NGO's, donors, marginalized } \\
\text { communities }\end{array}$ \\
\hline Nature conservation & $\begin{array}{l}\text { Small parts of governments, } \\
\text { nature advocates (environ- } \\
\text { mentalists), park managers, } \\
\text { tourism operators }\end{array}$ & National & $\begin{array}{l}\text { Potentially feeds into living } \\
\text { museum narrative }\end{array}$ & $\begin{array}{l}\text { Tourism industry, govern- } \\
\text { ments }\end{array}$ \\
\hline Landscape nexus & $\begin{array}{l}\text { Intergovernmental organi- } \\
\text { sations, Governments, } \\
\text { Researchers }\end{array}$ & Global to national & $\begin{array}{l}\text { Intending to integrate } \\
\text { economic transformation, } \\
\text { indigenous rights and } \\
\text { nature conservation }\end{array}$ & Researchers, governments \\
\hline Living museums & $\begin{array}{l}\text { Tourists and tourism opera- } \\
\text { tors, Governments }\end{array}$ & National to regional & $\begin{array}{l}\text { Used to discredit indigenous } \\
\text { rights narrative; In opposi- } \\
\text { tion to economic transfor- } \\
\text { mation }\end{array}$ & $\begin{array}{l}\text { Tourism industry, govern- } \\
\text { ments }\end{array}$ \\
\hline
\end{tabular}

\section{The economic transformation and modernization narrative}

The economic transformation and modernization narrative promotes large infrastructure developments by embracing the processes of electrification and rapid industrialization. In the context of water management, this narrative has a long history in the "hydraulic mission" of "state water bureaucracies" (Molle et al. 2009), where statehood is built around the narrative of societal advancement through the benefits of large dams and irrigation projects. It is particularly prominent in countries such as Ethiopia, where the "ethno-federal project" has been coopted by a top-down "developmental state" agenda (Woldegebrael 2018). Economic transformation and modernization may be the most recognized narrative within both Ethiopia and Kenya and it is increasingly shaping realities on the ground. When travelling overland in Ethiopia and Kenya, investments in road network upgrading, electrification, and other infrastructure such as mobile phone networks are widely visible (Fig. 3). In Kenya, and particularly within the Turkana basin, the promise of cheap hydropower to be purchased from Ethiopia's Gibe III dam is the hoped-for key to increasing the living standards of the communities within the basin. In addition, development projects within the Lake Turkana area are slowly opening the once marginalized region, for example for a large wind farm project which has been predicted to increase Kenyan electricity production by $18 \%$, providing incentives for migration and leading to an increase in land prices (Cormack and Kurewa 2018).
Large hydropower dams are symbolic in the economic transformation and modernization narrative, as they are considered crucial for supporting and expanding industries, agriculture and services. According to the Italian company responsible for the construction of Gibe III, the hydropower plant boosted Ethiopian energy production by $85 \%$ (Salini Impreglio 2019). The anticipated electricity output promises large-scale electrification, more stable industrial production and energy exports to neighboring countries for profit. Such projects serve as symbols of the hope for a better future and can unite people across politically divided parts of society. Examples are the widely shared social media hashtag

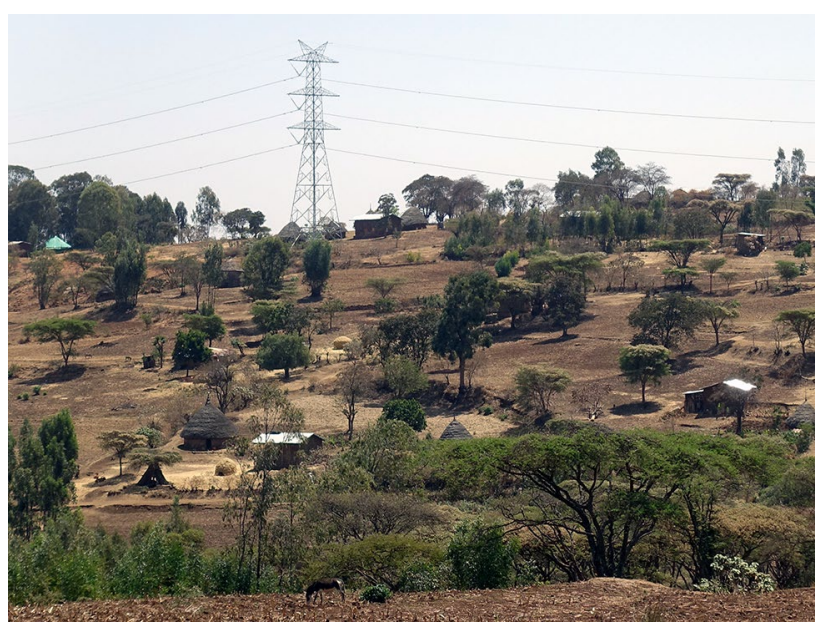

Fig. 3 Powerline in the upper catchment of the Omo River (photo by F. Kleinschroth, 21/03/2019) 
"\#itsmydam" on Twitter, or anonymous online statements such as: "Go Ethiopia! Only these kinds of bold and big projects will propel our country to the next phase of economic prosperity. And they said it could not be done" (Costantinos 2011, p.6).

Part of the modernization narrative is the transformation of subsistence economies to industrialized economies. Infrastructural investments like large dams and irrigated agriculture are seen as a path to achieving this goal while improving the livelihood of the rural population (Plusquellec 2009; Mastrangelo and Aguiar 2019). Large infrastructure projects in the Omo-Turkana basins are expected to have enormous implications for transforming the lives of peoples and landscapes also at the margins (Mosley and Watson 2016). As the then prime minister, Meles Zenawi, stated in a 2011 speech, the large dams on the Omo River are seen as the epitome of modernity (Zenawi 2011). Controlling the flow of a river not only allows stable production of electricity but also flood protection and year-round water availability for irrigation, thus providing food, electricity and job opportunities to formerly nomadic populations in the basin in order to allow them to settle in towns and villages and live a modern life.

\section{The indigenous rights narrative}

The prominent counterpart in the discussions about the Omo-Turkana case on an international level are concerns about the threats of dam construction to the lifestyle or even survival of pastoralist tribes in the Lower Omo Valley and in the Turkana basin. The lives of indigenous groups such as Mursi, Hamer, Karo, Nyangatom and Dassanech have long been the subject of anthropological studies (Carr 1977; Turton 1977; Turton and Turton 1984; Strecker 1997). The traditional lifestyle of these peoples, which relies on annual flooding for recession agriculture and on seasonal fluctuations in the Omo River for grazing lands, is well documented (Carr 2017). Another major concern affecting communities has been the reduction of overall flows into Lake Turkana due to abstraction for irrigation, leading to a reduction in lake levels, which potentially affects the future of the fisheries upon which the Turkana community in Kenya depends (Gownaris et al. 2017; Avery and Tebbs 2018). The planning phase of both Gibe III and Kuraz Sugar was accompanied by highly vocal criticism from representatives of international human rights NGOs and scientists, who warned against the development of both the dams and the sugar cane plantation (Human Rights Watch 2012). One important argument is that the towns and cities that benefit most from hydropower production are located outside the basin itself, while the local population pay the price of the unintended consequences resulting from the projects (Mosley and Watson 2016).
Advocates of the indigenous rights narrative want to see local populations included in decision-making processes and question that these communities have freely given informed consent to change their traditional lifestyles in favor of the modern lifestyles that would result from the modernization plans of the government. For example, the organization Survival International provides a template letter for international supporters to post to the Ethiopian president. The letter states:

"The Ethiopian Constitution guarantees people the right to 'full consultation' about projects which affect them. Tribal peoples in the Lower Omo region have not been properly consulted about the plantations, the villagization projects will destroy their livelihoods if they go ahead." (Survival International 2020)

Advocates of the indigenous rights narrative consider the situation as a violation of the rights of these populations and such community acceptance comes at the expense of a complete loss of their traditional lifestyle, identity and access to resources. The NGOs Human Rights Watch published recordings of people expressing opinions such as this one:

"They are cutting down our bush and forest, and bulldozing our gardens. Then they want us to sell off all our cattle. No one is going to sell their cattle. They should go away. They should leave our forest alone and leave it to us to cultivate with our hands." (Human Rights Watch 2012, p.59)

These statements reflect an opposition to the infrastructure projects, linked to the immediate threat of the loss of land and disruption of water dynamics and the proposed shift from pastoralism to paid labor. These statements are being communicated by international NGOs who ask the questions, record, cut, translate, and publish the videos, which means the information may go through a certain filter to support the indigenous rights narrative.

\section{The nature conservation narrative}

The nature conservation narrative is less visible in contemporary discourses about the Omo-Turkana basins than the previous two, but we encountered it for example when discussing with park managers, who showed concern about the conversion and fragmentation of national park land due to sugar cane plantations and the required infrastructure. Historically, the nature conservation narrative is reflected in the establishment of multiple types of protected areas in Ethiopia since the 1960's, where the government aimed to protect wildlife and manage forest resources (FDRE 1997). Through their conservation policy, the Ethiopian 
government emulated the establishment of other NP across Africa, following a strict preservationist paradigm (Debelo 2012; Debella 2019). In this regard, Mr. Akallework Habtewold, the then minister of Agriculture and head of the Ethiopian delegation to UNESCO wrote a letter in 1963 to the director general of UNESCO the plan of the country to establish protected areas and requested support:

“... It is our wish to manage and develop national parks and wildlife reserves in such a way as to secure the preservation of the flora and fauna, which provide centres of biological and ecological research, and contribute to the growth of the national economy, especially through development of tourism and game cropping in Ethiopia....' (Huxley et al. 1963, p.6)

The lower Omo region has particularly high levels of faunal and floral biodiversity (Haack 1996). For a long time, the region has been imagined as a mega-wildlife reserve and ecologists and nature lovers valued it for its' "unspoiled wilderness" (Turton 2011). Currently in the lower Omo there are four national parks (NP) and one wildlife reserve area, which together occupy more than $8800 \mathrm{~km}^{2}$, which is $11.2 \%$ of the Omo sub-basin, and two controlled hunting areas (Ethiopian Ministry of Culture and Tourism 2016). The total area designated for nature conservation is, therefore, more than ten-fold larger than the currently designated commercial agricultural area for sugarcane planations. Around Lake Turkana, the Kenyan Wildlife Service (KWS) and the National Museums of Kenya (NMK) co-manage the Lake Turkana National Parks that were established due to their "unique geomorphological features with fossil deposits on sedimentary formations as well as one hundred identified archaeological and paleontological sites. The existing ecological conditions provide habitats for maintaining diverse flora and fauna" (UNESCO 2021).

Historically, wildlife conservation in Ethiopia followed a protectionist philosophy where the main approach was "command and control" (Tesfaye and Wolff 2014; Debella 2019). In general, the nature conservation narrative is in conflict with major infrastructural development and agricultural expansion plans, which creates tensions and disagreements between government bodies (Abunie 2000). For example, in the lower Omo region the state-owned Ethiopian Sugar Corporation aims at expanding irrigated sugar plantations, while the Ethiopian Wildlife Conservation Authority is entrusted with keeping the wildlife areas undisturbed by agricultural expansion. Rooted in ecocentric views and the preservation ethic and movement of the 1960s, the nature conservation narrative leaves little room for the development plans of governmental bodies, livelihood improvements of the indigenous community or modernization, but rather seeks a pristine environment and wilderness (Turton 2011; Debelo 2012; Debella 2019). In terms of economic activity, this narrative sees tourism as the main potential source of income.

\section{The landscape nexus narrative}

The landscape nexus narrative combines views of interdisciplinary researchers and planners who suggest that the fundamental issue with decision-making is a lack of optimization in resource distribution due to lack of empirical evidence available to decision-making processes and the risk of "loselose" situations. Hence, this narrative is a response to the previously described narratives, as it aims to include multiple development narratives with the watershed as a boundary object (Cohen 2012). The water-energy-food nexus concept stresses the importance of moving away from siloed sectoral and discipline-oriented approaches in research, governance and management to a more integrated, holistic approach where tradeoffs can be identified and integrated solutions developed. The approach has become increasingly popular to capture multiple sectors and interests in water-related decision-making (Harwood 2018), similar to "landscape approaches" for land-related issues (Sayer et al. 2013). Here, the nexus narrative proposes to use empirical evidence of water availability to inform resource distribution negotiations across the nexus of water, energy, food security and ecosystem functioning. For the Omo-Turkana basins, this means developing scenarios for water resource distribution among different water users and uses and taking into consideration changing future water availability under climate change. The landscape nexus narrative attempts to be independent of any political interests by presenting as objectively as possible what is available so that all interested parties can negotiate solutions that allow for the optimal distribution of resources.

The EU has funded multiple projects that followed nexus narratives, of which some were strongly based on resource use optimization strategies, while others argue against optimization. The DAFNE project was oriented towards optimization, with the development of powerful computational models that aimed to encompass multiple narratives within the following framework:

"We hypothesize that establishing a DAF [decision analytic framework] based on the Participatory and Integrated Planning (PIP) procedure allows the evaluation of the WEF [Water Energy Food] nexus with the necessary perspective to investigate the impacts of infrastructural developments on the social, economic, and ecological dimensions of the river basins, and to assess ex-ante the alternative decision pathways based on such an investigation." (DAFNE consortium 2016) 


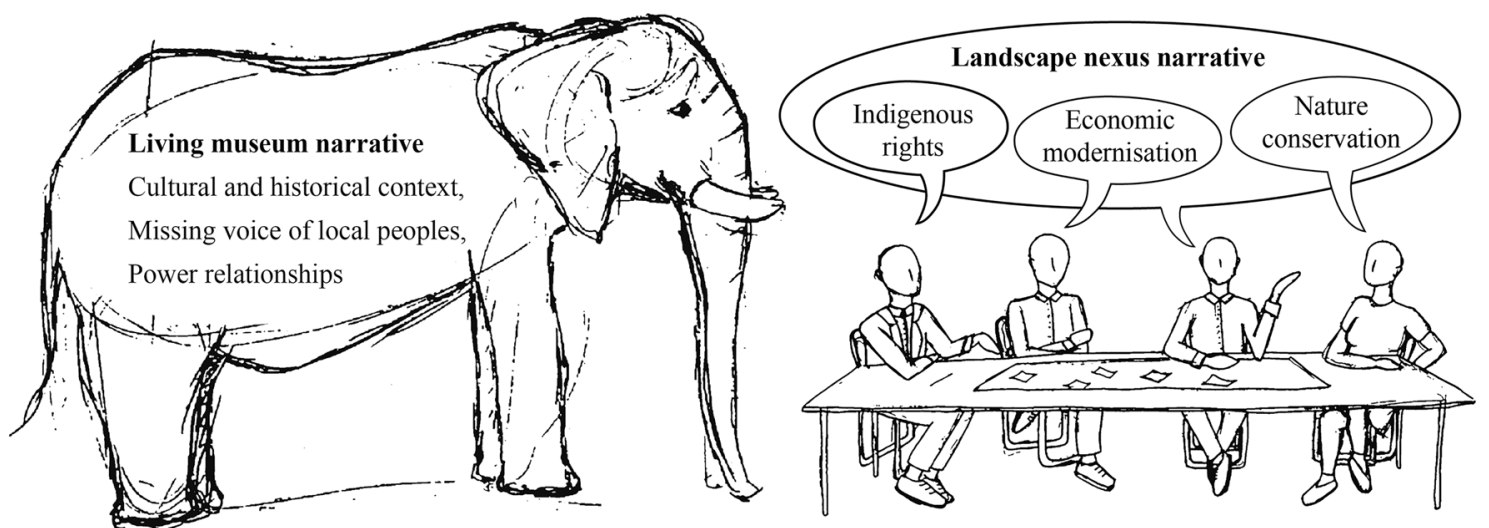

Fig. 4 Illustration of the relationship between the five identified narratives with the living museum narrative and underlying biases representing an elephant in the room of nexus negotiations (drawings by Helena Mühlhaus)

The implicit expectation from the outset of the project was that it would be implemented in a way that would consider multiple narratives and would provide an evidencebased perspective. While this is considered a standard approach in science, after engaging more closely with researchers and stakeholders in the riparian countries, we observed that the credibility of externally-funded research on development-related subjects was being questioned by some researchers and politicians in the basin countries. In the highly politicized context of transboundary water management and the construction of large dams, the claim of objectivity can be overly optimistic.

Climate change predictions are an important element of the landscape nexus narrative. The declared global state of climate emergency is often justified by increasing threats of the climate change for rural Africa (Serdeczny et al. 2017), but rarely are rural communities asked if and how these threats are actually materializing. On the contrary, the putative predictability of future scenarios through large computational models provides an authority that can be perceived as a threat in itself by people who live in the area or region under consideration who become objects of well-meaning but disconnected or generically applied technological approaches (Verhoeven 2014).

\section{The living museum narrative}

While the four previous narratives are openly used by their respective proponents, the living museum narrative is mostly used to discredit the indigenous rights narrative by its' opponents. It is based on the charge that some western scientists and NGOs want to "maintain" areas within countries like Ethiopia and Kenya as living museums of "traditional" lifestyles. Within the affected country, the putative reasons for such a living museum are that former colonial states want to maintain influence over the people and their traditional lifestyles to have access to them as objects of scientific research and tourism. The overall argument is described by Turton (2018):

"It has become commonplace for Ethiopian government officials to portray critics of their development policies as "anti-development" and/or as having a vested interest in the preservation of "backward" cultures. [...] Presenting the issue in this way has two main attractions for politicians and government officials. First, it allows them to avoid any serious engagement with the arguments and recommendations of their critics. Second, it allows them to ignore the single most important question raised by the worldwide literature on development-forced displacement, namely how to ensure that development projects which displace people genuinely benefit those who have to get out of the way to make them possible." (Turton 2018, pp. 59-60)

Inclusive, evidence-based approaches such as the landscape nexus narrative struggle with the living museums narrative, as it is based on the politically motivated imputation that external actors (such as European researchers) have a hidden agenda disguised by indigenous rights and conservation narratives.

Since the living museum narrative is very powerful in the discourse, we consider it important to try to understand how this narrative relates to the long history of exploitative Western research in Africa and ongoing inequality in access to knowledge and funding. We consider the emergence of the living museum narrative to be an indicator of the presence of a much larger elephant in the collaborative research room, representing Western or neocolonial biases which can be perceived in fundamentally different ways by European and African partners involved in a research process (Fig. 4). We consider it of crucial importance to any collaborative research, to understand the origins and reasons for these 
biases. An explanation of the origins of the living museum narrative provides an entry point in this regard.

The term "living museum" is highly visible in the Ethiopian tourism industry. In particular, the Lower Omo Valley caters to ethno-cultural tourism, where mainly Western tourists "visit" the various tribes. These visits typically consist of taking photographs and filming for which the tourists have to pay the individuals or communities which are the object of their attention directly (Turton 2004). Increasing accessibility for tourists, together with the ease with which photographs can be published on the internet have led to the global dissemination of such images. Photographs representing "primeval indigeneity" and "tribal identity" are being recycled and introduced in new discursive forms (Abbink 2009). An image search on the internet using the terms 'Omo River Ethiopia' reveals images of bare-chested women and girls adorned in beaded necklaces, young boys and men with decorated faces painted in white ash. The language of tour operators and guide books promotes the Lower Omo Valley and Turkana region as the "last paradise" and a "living museum":

"Culturally, southern Ethiopia is extraordinarily rich with some 56 languages spoken by people of many different ethnic origins. Here of special interest are groups of South Omo people, who live on the boundaries of Mago and Omo National Parks that preserve their traditional ways of life hardly changed from what they were centuries ago. To anthropologists, South Omo is not far from being the proverbial "Living Museum" - a museum whose inhabitants seem intent on rituals and decorations. Body scarring, lip plates, bull jumping - in different parts of South Omo these are all parts of the way of life." (Dan Sunshine Tours 2020)

The Ethiopian government refers to the living museum narrative often in combination with the dichotomy between modernity and "backwardness". The former Ethiopian Prime Minister, Meles Zenawi, characterized the region as "backward", meaning not part of the modern way of life and in need of a conversion (Zenawi 2011). Here, we interpret the definition of what is modern and what is backwards not primarily in comparison with Europe, but rather with Ethiopia's own uninterrupted civilizations (referring to statehood and administration; philosophy and writing, architecture, etc.; see for example, Eshete 2013). In the eyes of the government, the campaigns against the dam and the sugar plantation were led by mainly western organizations in an attempt to preserve the region in its current state.

"There are some people who want to block our freedom to use our rivers, and to save our people from poverty. They are creating huge propaganda, but they don't stop there. They are blocking us from getting financial loans from abroad to finish the project. There are also some people who are the best friends of backwardness and poverty, but claim to be concerned about environmental conservation. They do not actually do anything tangible. They just want to keep the pastoralists as a tourist attraction and make sure no development happens in pastoral areas. They team up with the people who don't want us to use our rivers to broadcast their propaganda" (Zenawi 2011). ${ }^{1}$

The use of the living museums narrative introduces an ethical dilemma to Western attempts that aim to promote social justice for indigenous peoples in the African context. Advocates of the economic transformation narrative can use the living museum narrative as a knockout argument against the inclusion of human rights or nature conservation viewpoints in science for sustainable development. This somewhat wicked situation may be rooted in the questionable role of green-growth-oriented sustainable development itself. Even if supported by governments around the world, sustainable development and the related idea of the green economy are Western cultural products, where the agents of structural power dictate what a developed society looks like (Kothari et al. 2014). This globally asymmetric relationship may cement local and national actors' perception of being trapped in a living museum. Expanding the divide, the polarization between global and local makes it even more necessary, yet difficult, for collaborative research to fully capture local perspectives and their plurality.

\section{What are the narratives of the local population?}

The communities in the Lower Omo Valley and Lake Turkana are diverse, practicing various ways of life in close proximity to each other. This makes it difficult to identify one narrative that represents the interests of "the" local communities. Local narratives concerning land and water resources are often presented on the basis of spiritual and religious beliefs that stem from a sense of place (Turton 2005; Buffavand 2016), which comes with a high diversity of views of the future. Common narratives on the implementation of large-scale infrastructure represent top-down approaches and polarized opinions. In addition, the "local" perspective is obscured by the images portrayed of extreme poverty among communities in need of external help from Western countries and NGOs, reinforced, following Bell (2013) and Straubhaar (2015), by the patronizing role that

\footnotetext{
1 The statement may refer to the decision of the World Bank to refuse funding of the Gibe III dam due to international criticism. In the end, funding was secured from Chinese investors (The Oakland Institute 2019)
} 
foreign aid organizations often play as donors. As Rettberg (2010) documented for a similar case in the Ethiopian Afar region:

"Narratives of risk and vulnerability are not simply representations of perceived threats, but they are also representations of asymmetric power relations between the agents of communication. Therefore, the local risk discourse towards outsiders and the internal discourse differ significantly. The pastoralists' emphasis of collective suffering and being at risk of multiple external enemies also [sic.] is also intended to attract support from more powerful outsiders." (Rettberg 2010, p.261)

The DAFNE project stakeholder workshops involved speakers from the Ethiopian Pastoralist Research \& Development Association and the Pastoralist Development Network of Kenya, each representing pastoralist's interests at national levels. We further conducted interviews with leaders and local administrators within the Lower Omo region. While we acknowledge that these sources may not be representative for the wider population, the outcome of these conversations revealed a mix of different narratives. We noticed an appreciation for the immediate benefits generated through local infrastructure investments such as roads and small-scale irrigation projects, which are part of the economic transformation and modernization narrative. Yet, regarding the large-scale dam and irrigation projects, skepticism prevailed, mostly related to the lack of information about long-term consequences for the region and broken promises of compensation through schemes that were not maintained over longer periods of time. As part of the indigenous rights narrative, some people indicated that transparency and participation were missing or were minimal in the river basin management process. There may simply not be one agreed-upon concept of development, given the complex realities shaped by traditions and history, but also national and global dependencies and influences, environmental constraints, resource struggles and related violent conflicts within the region.

\section{Discussion}

Trade-offs between economic development and the human right to self-determination of indigenous peoples are difficult to reconcile. Of an estimated population of 115 million in Ethiopia, about $80 \%$ live in rural areas of which $15 \%$ are pastoralists, with many of them more or less falling under the World Bank's definition of "indigenous" (Berger 2019; World Bank 2019). Yet the terms "indigenous" and "tribal" can be contentious in some countries or regions and may even be perceived to have a negative connotation by some of the communities in question. Neither Ethiopia nor Kenya have signed the United Nations Declaration on the Rights of Indigenous Peoples (UNDRIP, UN General Assembly 2007). A process of self-identification as indigenous or aboriginal and the fight for legal recognition of the associated rights, which is ongoing for example in North America and Australia, is only just beginning in the African context (Inman et al. 2018). ${ }^{2}$ This leads to a situation where international NGO's, rather than local communities dominate the indigenous rights narrative, making their concerns susceptible to being twisted into the living museums narrative by advocates of the economic transformation narrative.

It is difficult to identify coherent individual preferences of people who are regarded as indigenous, but nevertheless a lot is communicated on a global level about what indigenous lifestyles comprise. This disconnectedness tends to perpetuate the "ecologically noble savage myth" (Redford 1991) where indigenous peoples are portrayed as elements of otherwise intact landscapes, protecting their natural integrity through inherently sustainable practices. Such romantic ideals of sustainable resource uses by indigenous peoples are abundant in the nature conservation literature (Hames 2007), and they provide arguments favoring the living museums narrative. Ethiopia, like many other African countries, has a history of nature conservation that is characterized by top-down implementation of protected areas, enforced by authorities with insufficient consideration to resident communities and this has led to high levels of tension between local populations and conservation interests over the last few decades (Turton 1988; Tessema et al. 2010). Despite the rhetoric about community approaches to nature conservation, the interests of conservationists who want to protect wilderness are inherently different from those of pastoralists (Turton 2002). During a visit to Omo National Park, park rangers showed us a dead lion. According to the rangers, the lion was killed by a pastoralist whose goat had been eaten by the lion. This anecdotal incident demonstrates the actual difficulty in reconciling the interests of people and wildlife conservation.

\section{Planning adaptive landscapes not living museums}

The goal of maintaining adaptive landscapes is the opposite of the goal of maintaining a living museum, which would be to maintain a fixed (historic) state. It may sound counterintuitive, but increasing global connectivity, both digitally through the internet and physically through improved mobility, has allowed the production and reproduction of images

\footnotetext{
2 There are significant regional differences, for example , in Kenya, after a case made by the Endorois communityrecognized the rights of marginalized communities and traditional communities (Inman et al 2018)
} 
of peoples of the South Omo and Turkana region that are now fueling emotions and romantic ideas. Most Ethiopians and Kenyans, however, do not want such images to be representative of their societies. Although 35 years have passed since the huge Live Aid concert raised funds for the famine in Ethiopia, the country is still struggling to dislodge its label as a receiver of foreign aid and instead to be known for its long and rich cultural history and fast-growing economy. This may be one of the reasons why the economic transformation narrative is strongly advocated by much of Ethiopian society.

If we as scientists want to be in the position to contribute to a fertile ground for identifying solutions albeit with compromises, we must try to avoid any complicity with "green imperialism" (Grove et al. 1996) or what is perceived as such in the Global South. Any kind of paternalism towards indigenous peoples and their associated lifestyles is in opposition to the essential right of all people to self-determination or, simply to "be different" as stated in UNDRIP. Communitybased natural resource management needs to move away from assumptions about what people want and refocus on ensuring social justice, material well-being and environmental integrity (Dressler et al. 2010). The more diverse the actors in a decision-making process, the more resilient social-ecological systems become to global change (GrêtRegamey et al. 2019). A landscape forced into a museumlike state is at risk of losing its resilience to environmental and societal changes that will inevitably occur over the next few decades.

\section{The danger of a single story}

Each of the narratives described is based on collective values, priorities and perceptions of what a good life or a good society is. Yet, they are also the outcomes of trade-offs between national development priorities and access to land and water resources for individuals on the ground. Using or promoting only a single narrative, can be an effective way to manifest a position of power for negotiations concerning resource management in a context of resource scarcity. In a popular TED talk, Nigerian writer, Chimamanda Ngozi Adichie, talks about the risks of telling stories about people and regions with only a single narrative. As an alternative, she highlights the importance of accepting many different stories that are all part of the bigger picture: "Stories matter. Many stories matter. Stories have been used to dispossess and to malign, but stories can also be used to empower and to humanize. Stories can break the dignity of a people, but stories can also repair that broken dignity." (Adichie 2009).

Scientific approaches typically claim to be based on evidence in the form of measured data or other empirical proof. Especially many water-management-related nexus approaches promise technically optimized compromise solutions that are seemingly independent of political discourses. Yet, this neglects the fact that every person and every region have a history and nobody living in that place will act completely independent of that history. Decisionmaking is therefore political and cannot be disentangled from the question of who perpetuates a certain narrative and who will benefit from it. Epistemologies in the African context might be entirely different from those in the Western context, which suggests the need for diversity in meaning-making:

"We need to take a fresh approach that values African epistemologies and ways of knowing and that nurtures local talent to take the lead. To solve African problems, there is an urgent need to see the situation through an African lens - both when defining the problem and coming up with locally relevant solutions." (van Stam 2019, p. 55)

This lens is beginning to change. The DAFNE project and the associated landscape nexus narrative explicitly aimed to contribute to a more balanced and fair distribution of water-related benefits (Liu et al. 2018). The project involved a range of stakeholders from water-energy-food sectors as well as from tourism and culture and organizations representing pastoralists in the two countries. They were involved from the outset of the project to identify issues in the region and eventual management strategies. Institutional frameworks of water governance as well as the biophysical and socio-economic state of and trends in the basins were examined together with the potential impacts of legal and policy frameworks. Yet, the living museum narrative and the related elephant of cultural biases in the room (Fig. 4) only appeared during the project implementation and at this point the possibilities to take it into account were limited. At a minimum, we could only try to understand and communicate the narrative. Even when using highly technical research approaches, we need to acknowledge human experience, cognition and values from culturally-specific narratives and only when we learn to tell these stories, will we be able to frame "knowledge work" in a collaborative manner (Paschen and Ison 2014).

\section{Pathways ahead}

As a way forward, we compiled four key points from existing recommendations for fairness, respect, care and honesty in international research projects in an effort to promote transparency and trust and ultimately more effective collaboration for the benefit of the regions that are the focus of the research.

1. Ensure involvement of and relevance to local partners and communities: The research carried out should be relevant to the location in which it is taking place and this can be determined in collaboration with local partners and where possible, 
the affected communities, who ideally should be actively engaged in the project in the planning phase and throughout the project (TRUST Equitable Research Partnerships 2018). Evaluations and feedback sessions with community members or their representatives as well as with local partners before, during and after the project can be a highly effective means of assessing needs and effectiveness of research goals, approaches and methods.

2. Make hidden interests explicit: Each partner involved should be asked to make their organizational/institutional as well as their individual interests with respect to project activities explicit when the project is in the conceptualization stage (Ralphs and Wagner 2018). These perspectives can be collected in a written form or in a workshop, if resources permit, and then shared with all partners so that any conflicts can be resolved in advance. This exercise naturally relies on the willingness of those participating to be open and honest.

3. Identify ways in which various identities (linguistic, gender, cultural, national, etc.) influence the effectiveness of the research to be carried out (Ralphs and Wagner 2018). As Ralphs and Wagner (2018, p.134) rightly point out, there is often a "pretence that all collaborators are equally educated, all globally connected, and that there is no cultural barrier". While recognizing this statement, we have also observed that this pretense is not held by all researchers, especially those from the region where the research is to be carried out. In a workshop setting, experiences from previous international projects could be shared to identify ways to ensure effective cultural communication and to begin the team-building process in atmosphere of greater trust.

4. Obtain informed consent from the owners or custodians of local resources including traditional knowledge prior to beginning research (TRUST Equitable Research Partnerships 2018). Free prior and informed consent (FPIC) is the backbone of any involvement of local and indigenous communities and should never be taken for granted without being obtained in advance.

The recommendations from the Global Code (TRUST Equitable Research Partnerships 2018) has been adopted by the EC as a mandatory reference document for the Horizon 2020 research funding program. Yet, addressing these recommendations in a meaningful way takes time and most of this work must be done at the preparation stage, typically before the project is funded. One main problem is that the time to design a scientific project is limited, and the probability that the project will be selected for funding in the highly competitive EU grants environment is low. This dilemma could only be overcome, if funding bodies would compensate researchers already during the design phase of a project, e.g. through seed funding, to allow researchers to consult and negotiate with other key actors to develop a better understanding of the variety of existing narratives and accordingly the needs.

\section{Conclusions}

The narratives that we encountered through our work have multiple functions. They can be growth-oriented, such as the economic transformation narrative; empowering, such as the indigenous rights narrative; integrative, such as the nexus narrative; but they can also serve to undermine other narratives such as the living museum narrative. Any collaborative research project with African and European participants needs to provide space for critical reflection on culturally, historically or politically-determined personal and structural biases, and the flexibility to adapt research questions and approaches accordingly. Given historical and political complexity, research on the water-energy-food nexus is largely dominated by technical approaches, as lamented in a recent editorial in the journal Nature Sustainability:

"[...] water studies as a field may have largely given up on historical context and institutional change, suggesting that as water studies has become more quantified and technically driven, it has also become less grounded. [...] Engineering solutions to water problems are portrayed in elegant terms that may appear simple and make us feel better, precisely because they ignore the messy institutions, norms and processes that underlie our relationship, as individuals and as a society, with water in the first place." (Editors of Nature Sustainability 2021)

Even if our narrative approach does not capture the full range and complexity of voices at different scales, their articulation can help stimulate critical reflection amongst project partners with different backgrounds. Research practices for sustainability need to be more than the sum of the parts provided by contrasting narratives, but rather the process of creating a common understanding in an environment that is increasingly determined by extreme competition for resources.

Supplementary Information The online version contains supplementary material available at https://doi.org/10.1007/s11625-021-01044-4.

Acknowledgements The research in which the co-authors were involved and from which examples were drawn for this article was funded through the DAFNE project by the European Commission. As such, the article reflects the views and independent research solely of the authors. We thank Scott Sinclair, Evelyn Lukat, Johannes Halbe, Laura Herzog, Larissa Koch, Philipp Gross, Christian Knieper, Kavita Sharma, Fanny Olsthoorn, Nicole Kalas, Sara Löfqvist and the Ecosystem Management group at ETH Zurich for their helpful comments and discussions. Helena Mühlhaus kindly made the drawings for Fig. 4. We are grateful to Gnekuma Asrat and Bini Z. Tobi for their support in the field. We also thank all the stakeholders engaged in the Negotiation Simulation Lab meetings and those who we met in the South Omo region during our field work for kindly sharing their viewpoints and information. Two anonymous reviewers helped to improve the manuscript with their constructive comments. 
Funding Open Access funding provided by ETH Zurich. Horizon 2020 programme (Grant Number 690268).

Open Access This article is licensed under a Creative Commons Attribution 4.0 International License, which permits use, sharing, adaptation, distribution and reproduction in any medium or format, as long as you give appropriate credit to the original author(s) and the source, provide a link to the Creative Commons licence, and indicate if changes were made. The images or other third party material in this article are included in the article's Creative Commons licence, unless indicated otherwise in a credit line to the material. If material is not included in the article's Creative Commons licence and your intended use is not permitted by statutory regulation or exceeds the permitted use, you will need to obtain permission directly from the copyright holder. To view a copy of this licence, visit http://creativecommons.org/licenses/by/4.0/.

\section{References}

Abbink J (2009) Suri Images: the return of exoticism and the commodification of an ethiopian "tribe." Cah Etud Afr 49:893-924. https://doi.org/10.4000/etudesafricaines. 15698

Abunie L (2000) The challenges of conserving Ethiopian wildlife. Walia 21:56-62

Adichie CN (2009) The danger of a single story. In: TEDGlobal. https://www.ted.com/talks/chimamanda_ngozi_adichie_the_ danger_of_a_single_story/up-next. Accessed 1 Feb 2020

Amos S, Mengistu S, Kleinschroth F (2021) Three decades of pastoralist settlement dynamics in the Ethiopian Omo Delta based on remote sensing data. Hum Ecol. https://doi.org/10.1007/ s10745-021-00257-6

Avery ST, Tebbs EJ (2018) Lake Turkana, major Omo River developments, associated hydrological cycle change and consequent lake physical and ecological change. J Great Lakes Res 44:11641182. https://doi.org/10.1016/j.jglr.2018.08.014

Ayalew L (2009) Analyzing the effects of historical and recent floods on channel pattern and the environment in the Lower Omo basin of Ethiopia using satellite images and GIS. Environ Geol 58:1713-1726. https://doi.org/10.1007/s00254-008-1671-8

Bell KM (2013) Raising Africa?: Celebrity and the rhetoric of the white saviour. PORTAL J Multidiscip Int Stud 10:1-24. https:// doi.org/10.5130/portal.v10i1.3185

Berger DN (2019) The indigenous world 2019. International Work Group for Indigenous Affairs, Copenhagen

Brodkey L (1987) Writing critical ethnographic narrative. Anthropol Educ Q 18:67-76

Buffavand L (2016) 'The land does not like them': contesting dispossession in cosmological terms in Mela, south-west Ethiopia. J East African Stud 10:476-493. https://doi.org/10.1080/17531 055.2016.1266194

Cabello V, Kovacic Z, Van Cauwenbergh N (2018) Unravelling narratives of water management: Reflections on epistemic uncertainty in the first cycle of implementation of the Water Framework Directive in southern Spain. Environ Sci Policy 85:19-27. https://doi.org/10.1016/j.envsci.2018.03.019

Carr CJ (2017) River basin development and human rights in Eastern Africa: A policy crossroads. Springer Open, Cham, Switzerland

Carr CJ (1977) Pastoralism in crisis: The Dasanetch of Ethiopia and their lands. University of Chicago, Department of Geography, Research Paper 180, Chicago

Charmaz K (2006) Constructing grounded theory: A practical guide through qualitative analysis. In: Introducing Qualitative Methods

Chun Tie Y, Birks M, Francis K (2019) Grounded theory research: a design framework for novice researchers. SAGE Open Med
7:205031211882292. https://doi.org/10.1177/2050312118 822927

Cohen A (2012) Rescaling environmental governance: Watersheds as boundary objects at the intersection of science, neoliberalism, and participation. Environ Plan A 44:2207-2224. https://doi.org/ $10.1068 / \mathrm{a} 44265$

European Commission (2018) Roadmap for EU-African Union S \& T cooperation. European Commission, Brussels

European Commission (2019) Africa and Horizon 2020. European Commission, Brussels

Corbin J, Strauss A (1990) Grounded theory research: Procedures, canons and evaluative criteria. Z Soziol 19:418-427. https://doi.org/ 10.1007/BF00988593

Cormack Z, Kurewa A (2018) The changing value of land in Northern Kenya: the case of Lake Turkana Wind Power. Crit African Stud 10:89-107. https://doi.org/10.1080/21681392.2018.1470017

Costantinos BT (2011) Nascent spurts towards a nation of promises and possibilities: The Nile and Gilgel Gibe III controversy and the real intentions behind Ethiopia's drive to harness its natural resources

DAFNE consortium (2016) The DAFNE approach. http://dafne-proje ct.eu/about/approach/. Accessed 1 Feb 2020

Dan Sunshine Tours (2020) Omo Valley - The living museum. https:// dansunshinetours.com/OmoValley.html. Accessed 1 Feb 2020

Debella HJ (2019) "Command and control": 75 Years of quasi wildlife policy analysis of Ethiopia. J Int Wildl Law Policy 22:33-54. https://doi.org/10.1080/13880292.2019.1611217

Debelo AR (2012) Contesting views on a protected area conservation and development in Ethiopia. Soc Sci 1:24-46. https://doi.org/ 10.3390/socsci1010024

Di Baldassarre G, Sivapalan M, Rusca M et al (2019) Sociohydrology: Scientific challenges in addressing the Sustainable Development Goals. Water Resour Res 55:6327-6355. https://doi.org/10.1029/ 2018WR023901

Dressler W, Büscher B, Schoon M et al (2010) From hope to crisis and back again? A critical history of the global CBNRM narrative. Environ Conserv 37:5-15. https://doi.org/10.1017/S037689291 0000044

Editors of Nature Sustainability (2021) Too much and not enough. Nat Sustain. 4(8):659-659. https://doi.org/10.1038/ s41893-021-00766-8

Enns C (2018) Mobilizing research on Africa's development corridors. Geoforum 88:105-108. https://doi.org/10.1016/j.geoforum.2017. 11.017

Eshete A (2013) Modernity: Its title to uniqueness and its advent in Ethiopia from the lecture what is "zemenawinet"? Perspectives on Ethiopian modernity. Northeast Afr Stud 13:1-17. https://doi. org/10.1353/nas.2013.0004

Evans K, Murphy L, De Jong W (2014) Global versus local narratives of REDD: A case study from Peru's Amazon. Environ Sci Policy 35:98-108. https://doi.org/10.1016/j.envsci.2012.12.013

FDRE (1997) Envionmental Policy. Federal Democratic Republic of Ethiopia Environmental Protection Authority in collaboration with the Ministry of Economic Development and Cooperation, Addis Ababa

Gil-Romera G, Turton D, Sevilla-Callejo M (2011) Landscape change in the lower Omo valley, southwestern Ethiopia: Burning patterns and woody encroachment in the savanna. J East African Stud 5:108-128. https://doi.org/10.1080/17531055.2011.544550

Girke F (2013) Homeland, boundary, resource: the collision of placemaking projects on the Lower Omo River, Ethiopia. Max Planck Institute for Social Anthropology Working Papers 148. http://hdl. handle.net/11858/00-001M-0000-0014-CCA5-6

Gownaris NJ, Pikitch EK, Aller JY et al (2017) Fisheries and water level fluctuations in the world's largest desert lake. Ecohydrology 10:1-16. https://doi.org/10.1002/eco.1769 
Grasham CF (2016) Competing narratives of water resources management in Ethiopia. In: Niewöhner J, Bruns A, Hostert P et al (eds) Land Use Competition: Ecological, Economic and Social Perspectives. Springer International Publishing, Cham, pp 347-361

Grêt-Regamey A, Huber SH, Huber R (2019) Actors' diversity and the resilience of social-ecological systems to global change. Nat Sustain 2:290-297. https://doi.org/10.1038/s41893-019-0236-z

Grove R, Grove RH, Crosby AW, Worster D (1996) Green imperialism: colonial expansion, tropical island edens and the origins of environmentalism, 1600-1860. Cambridge University Press

Haack B (1996) Monitoring wetland changes with remote sensing: An east African example. Environ Manage 20:411-419. https://doi. org/10.1007/BF01203848

Hames R (2007) The ecologically noble savage debate. Annu Rev Anthropol 36:177-190. https://doi.org/10.1146/annurev.anthro. 35.081705.123321

Harwood SA (2018) In search of a (WEF) nexus approach. Environ Sci Policy 83:79-85. https://doi.org/10.1016/j.envsci.2018.01.020

Hodbod J, Stevenson EGJ, Akall G et al (2019) Social-ecological change in the Omo-Turkana basin: a synthesis of current developments. Ambio. https://doi.org/10.1007/s13280-018-1139-3

Human Rights Watch (2012) "What will happen if hunger comes?" abuses against the indigenous peoples of Ethiopia's Lower Omo Valley. Human Rights Watch

Huxley J, Gille A, Monod T, et al (1963) The conservation of nature and natural resources in Ethiopia. UNESCO, Paris

Salini Impreglio (2019) Gibe III Hydroelectric Project. https://www. salini-impregilo.com/en/projects/dams-hydroelectric-plants/ gibe-iii-hydroelectric-project. Accessed 1 Feb 2020

Inman D, Cambou D, Smis S (2018) Evolving legal protections for indigenous peoples in Africa: Some post-UNDRIP reflections. African J Int Comp Law 26:339-365. https://doi.org/10.3366/ ajicl.2018.0236

Kamski B (2019) Water, sugar, and growth: the practical effects of a 'failed' development intervention in the southwestern lowlands of Ethiopia. J East African Stud 13:621-641. https://doi.org/ 10.1080/17531055.2019.1669374

Kolding J, van Zwieten P, Marttin F, Poulain F (2016) Fisheries in the drylands of sub-Saharan Africa - "Fish come with the rains". Building resilience for fisheries-dependent livelihoods to enhance food security and nutrition in the drylands. FAO Fisheries and Aquaculture Circular No. 1118. Rome, Italy

Kothari A, Demaria F, Acosta A (2014) Buen Vivir, Degrowth and Ecological Swaraj: alternatives to sustainable development and the Green Economy. Development 57:362-375. https://doi.org/ $10.1057 /$ dev.2015.24

Lakoff G (2010) Why it matters how we frame the environment. Environ Commun 4:70-81. https://doi.org/10.1080/17524 030903529749

Liu J, Hull V, Godfray HCJ et al (2018) Nexus approaches to global sustainable development. Nat Sustain 1:466-476. https://doi. org/10.1038/s41893-018-0135-8

Luederitz C, Abson DJ, Audet R, Lang DJ (2017) Many pathways toward sustainability: not conflict but co-learning between transition narratives. Sustain Sci 12:393-407. https://doi.org/ 10.1007/s11625-016-0414-0

Lyotard JF (1984) The Postmodern Condition: A Report on Knowledge. University of Minnesota Press

Mastrangelo ME, Aguiar S (2019) Are ecological modernization narratives useful for understanding and steering social-ecological change in the Argentine Chaco? Sustain. https://doi.org/10. $3390 /$ su11133593

Mawere M, van Stam G (2019) Paradigm Clash. Imperial Methodological Epistemologies and Development in Africa: Democr Good Gov Dev Africa. https://doi.org/10.2307/j.ctvk3gmq7.9
Mlambo AS (2006) Western Social Sciences and Africa: The Domination and Marginalisation of a Continent. African Sociol Rev 10:161-179

Molle F (2008) Nirvana concepts, narratives and policy models: Insights from the water sector. Water Altern 1:131-156

Molle F, Mollinga PP, Wester P (2009) Hydraulic bureaucracies and the hydraulic mission: Flows of water, flows of Power. Water Altern 2:23

Mosley J, Watson EE (2016) Frontier transformations: development visions, spaces and processes in Northern Kenya and Southern Ethiopia. J East African Stud 10:452-475. https://doi.org/10. 1080/17531055.2016.1266199

Ethiopian Ministry of Culture and Tourism (2016) Natural attractions. http://www.moct.gov.et/natural-attractions

Nickerson RS (1999) How we know - And sometimes misjudge What others know: imputing one's own knowledge to others. Psychol Bull 125:737-759. https://doi.org/10.1037/0033-2909. 125.6 .737

Ojwang WO, Obiero KO, Donde OO et al (2017) Lake Turkana: World's Largest Permanent Desert Lake (Kenya). In: Finlayson CM, Milton GR, Prentice RC, Davidson NC (eds) The Wetland Book. Springer, Netherlands, pp 1-20

Paschen JA, Ison R (2014) Narrative research in climate change adaptation - Exploring a complementary paradigm for research and governance. Res Policy 43:1083-1092. https://doi.org/10.1016/j. respol.2013.12.006

Plusquellec H (2009) Modernization of large-scale irrigation systems: is it an achievable objective or a lost cause? Irrig Drain 58:104120. https://doi.org/10.1002/ird.488

Ralphs G, Wagner IE (2018) Towards Better Joint Work: Reflections on Partnership Effectiveness. In: Cherry A, Haselip J, Ralphs G, Wagner IE (eds) Africa-Europe research and innovation cooperation: global challenges, bi-regional responses. Springer International Publishing, Cham, pp 123-140

Redford K (1991) The ecologically noble savage. Cult Surv Q 15(1):46

Reed MG, Bruyneel S (2010) Rescaling environmental governance, rethinking the state: A three-dimensional review. Prog Hum Geogr 34:646-653. https://doi.org/10.1177/0309132509354836

Rettberg S (2010) Contested narratives of pastoral vulnerability and risk in Ethiopia's Afar region. Pastoralism 1:248-273. https:// doi.org/10.3362/2041-7136.2010.014

Rieu-Clarke A (2015) Transboundary hydropower projects seen through the lens of three international legal regimes - foreign investment, environmental protection and human rights. Int $\mathrm{J}$ Water Gov 01:27-48. https://doi.org/10.7564/13-IJWG36

Roe EM (1991) Development narratives, or making the best of blueprint development. World Dev 19:287-300

Sayer J, Sunderland T, Ghazoul J et al (2013) Ten principles for a landscape approach to reconciling agriculture, conservation, and other competing land uses. Proc Natl Acad Sci 110:8349-8356. https://doi.org/10.1073/pnas.1210595110

Serdeczny O, Adams S, Baarsch F et al (2017) Climate change impacts in Sub-Saharan Africa: from physical changes to their social repercussions. Reg Environ Chang 17:1585-1600. https://doi. org/10.1007/s10113-015-0910-2

Shanahan EA, Jones MD, Mcbeth MK (2011) Policy narratives and policy processes. Policy Stud J 39:535-561. https://doi.org/10. 1111/j.1541-0072.2011.00420.x

Snow DA, E. Burke Rochford J., Worden SK., Benford RD. (1986) Frame alignment processes, micromobilization, and movement participation. Am Sociol Rev 51:464-481

Straubhaar R (2015) The stark reality of the 'White Saviour' complex and the need for critical consciousness: a document analysis of the early journals of a Freirean educator. Compare 45:381-400. https://doi.org/10.1080/03057925.2013.876306 
Strecker I (1997) The turbulence of images: On imagery, media and ethnographic discourse. Vis Anthropol 9:207-227. https://doi. org/10.1080/08949468.1997.9966703

Survival International (2020) Write a letter for the tribes of the Omo Valley. https://www.survivalinternational.org/actnow/writealett er/omovalley. Accessed 1 Feb 2020

Tesfaye G, Wolff M (2014) The state of inland fisheries in Ethiopia: A synopsis with updated estimates of potential yield. Ecohydrol Hydrobiol 14:200-219. https://doi.org/10.1016/j.ecohyd.2014. 05.001

Tessema ME, Lilieholm RJ, Ashenafi ZT, Leader-Williams N (2010) Community attitudes toward wildlife and protected areas in Ethiopia. Soc Nat Resour 23:489-506. https://doi.org/10.1080/ 08941920903177867

The Oakland Institute (2019) "How They Tricked Us" - Living with the Gibe III Dam and Sugarcane Plantations in Southwest Ethiopia. The Oakland Institute, Oakland, USA

TRUST Equitable Research Partnerships (2018) Global code of conduct for research in resource-poor settings. https://doi.org/10. 48508/GCC/2018.05

Turton D (1977) Response to drought: the Mursi of southeastern Ethiopia. Disasters 1:275-287

Turton D (1988) The Mursi and National Park development in the Lower Omo Valley. In: Anderson D, Grove RH (eds) Conservation in Africa. Cambridge University Press, Cambridge, pp 169-186

Turton D (2002) The Mursi and the elephant question. In: Chatty D, Colchester M (eds) Conservation and mobile indigenous peoples: displacement, forced settlement and development. Berghahn Books, New York/ Oxford, pp 1-19

Turton D (2004) Lip-plates and the people who take photographs. Anthropol Today 20:3-8

Turton D (2005) The meaning of place in a world of movement: Lessons from long-term field research in Southern Ethiopia. J Refug Stud 18:258-280. https://doi.org/10.1093/refuge/fei031

Turton D (2011) Wilderness, wasteland or home? three ways of imagining the lower Omo valley. J East African Stud 5:158-176. https:// doi.org/10.1080/17531055.2011.544546

Turton D (2018) Hydropower and irrigation development in the Omo Valley : development for whom ? Antropol Pubblica 4:51-64

Turton D, Turton P (1984) Spontaneous after drought: an Ethiopian resettlement example. Disasters 8:178-189

UN General Assembly (2007) Declaration on the rights of indigenous peoples United Nations. United Nations, New York

UNEP (2013) Balancing economic development and protecting the cradle of mankind-Lake Turkana basin. UNEP Global
Environmental Alert Service. https://wedocs.unep.org/20.500. $11822 / 8416$

UNESCO (2021) Lake Turkana National Parks. https://whc.unesco. org/en/list/801/

van Stam G (2019) Why do foreign solutions not work in Africa? Recognising alternate epistemologies. In: Van Reisen M, Mawere M, Stokmans M, Gebre-Egziabher KA (eds) Roaming Africa: Migration, resilience and social protection. Langaa Research \& Publishing CIG, Bamenda, Cameroon, pp 55-82

Veland S, Scoville-Simonds M, Gram-Hanssen I et al (2018) Narrative matters for sustainability: the transformative role of storytelling in realizing $1.5^{\circ} \mathrm{C}$ futures. Curr Opin Environ Sustain 31:41-47. https://doi.org/10.1016/j.cosust.2017.12.005

Velpuri NM, Senay GB (2012) Assessing the potential hydrological impact of the Gibe III Dam on Lake Turkana water level using multi-source satellite data. Hydrol Earth Syst Sci 16:3561-3578. https://doi.org/10.5194/hess-16-3561-2012

Verhoeven H (2014) gardens of eden or hearts of darkness? the genealogy of discourses on environmental insecurity and climate wars in Africa. Geopolitics 19:784-805. https://doi.org/10.1080/ 14650045.2014 .896794

Williams DR (2014) Making sense of "place": Reflections on pluralism and positionality in place research. Landsc Urban Plan 131:7482. https://doi.org/10.1016/j.landurbplan.2014.08.002

Wilson D (2012) Updating the global-local disorder concept (revisiting Peck and Tickell). Area 44:254-257. https://doi.org/10.1111/j. 1475-4762.2012.01092.x

Woldegebrael EH (2018) The Materialization of "Developmental State" in Ethiopia: Insights from the Gibe III Hydroelectric Development Project Regime, Omo Valley. Espac Polit 35. https://doi.org/10.4000/espacepolitique.4985

Wolka K, Sterk G, Biazin B, Negash M (2018) Benefits, limitations and sustainability of soil and water conservation structures in Omo-Gibe basin, Southwest Ethiopia. Land Use Policy 73:1-10. https://doi.org/10.1016/j.landusepol.2018.01.025

World Bank (2019) Indigenous Peoples Overview. https://www.world bank.org/en/topic/indigenouspeoples. Accessed 13 May 2019

Zenawi M (2011) Speech during the 13th annual pastoralists' day celebrations. http://www.mursi.org/pdf/Meles Jinka speech.pdf. Accessed 13 May 2019

Publisher's Note Springer Nature remains neutral with regard to jurisdictional claims in published maps and institutional affiliations. 